\title{
Prolonged Shedding of Zika Virus RNA in Vaginal Secretions, Nicaragua
}

\section{Yaoska Reyes, ${ }^{1}$ Natalie M. Bowman, ${ }^{1}$ Sylvia Becker-Dreps, Edwing Centeno, Matthew H. Collins, Guei-Jiun Alice Liou, Filemón Bucardo}

Zika virus, an arthropodborne flavivirus pathogen in humans, is unusual because it can be sexually transmitted and can be shed for prolonged periods in semen. We report viral shedding in vaginal secretions for up to 6 months, indicating the potential for sexual and vertical transmission by infected women.

$\mathrm{Z}$ ika virus swept through the Americas beginning in 2014, with $>1$ million cases reported through December 2017 (Pan American Health Organization, https://www. paho.org/hq/index.php?option $=$ com_docman\&task $=$ doc view\&Itemid $=270 \&$ gid $=43297 \&$ lang $=$ en). Zika virus had been considered relatively benign, but during the Americas epidemic, several new pathogenic features were identified: association with severe birth defects in infants born to women infected during pregnancy, transmission by sexual contact, prolonged shedding in semen, and Guillain-Barré syndrome (1-3). Shedding in the female genitourinary tract has not been widely reported and remains a serious question because of the potential for sexual transmission or ascending fetal infection in a pregnant woman (4).

\section{The Study}

During October 2016-November 2017, we recruited women $\geq 18$ years of age with symptomatic Zika virus infection (any combination of rash, fever, and conjunctivitis for $\leq 7$ days) at a public health center and Hospital Escuela Oscar Danilo Rosales Argüello in León, Nicaragua. We enrolled 5 women in a prospective cohort to characterize duration of viral shedding in the genital tract. We collected blood by venipuncture, and each woman provided urine and saliva samples.

We tested whole blood, urine, and saliva from each woman for Zika virus RNA at enrollment with quantitative reverse transcription PCR (qRT-PCR). If we detected Zika

Author affiliations: Universidad Nacional Autónoma de Nicaragua, León, Nicaragua (Y. Reyes, E. Centeno, F. Bucardo); University of North Carolina, Chapel Hill, North Carolina, USA (N.M. Bowman, S. Becker-Dreps, M.H. Collins, G.-J.A. Liou) virus RNA in any fluid, we asked women to provide blood, urine, saliva, and vaginal secretions at $7,14,21,28,60$, 90 , and 180 days postonset (dpo) of initial symptoms. We collected vaginal fluid using the BBL Culture Swab Collection and Transport System (Becton Dickinson, http:// www.bd.com). Vaginal swabs were self-collected by the woman, who inserted the swab $\approx 5 \mathrm{~cm}$ into the vagina, left it in place for 5 minutes, removed it, and placed it into swab transport media. Women did not provide samples during menstruation to avoid contamination with blood. Study staff transported the swab specimens at $4^{\circ} \mathrm{C}$ within 3 hours to the Universidad Nacional Autónoma de Nicaragua-León microbiology laboratory, where it was stored at $4^{\circ} \mathrm{C}$ for up to 4 months until RNA extraction.

To elute Zika virus RNA, we incubated vaginal swabs in $140 \mu \mathrm{L}$ of phosphate-buffered saline at room temperature for $10 \mathrm{~min}$. We extracted Zika virus RNA from the eluent using the QIAamp Viral RNA Mini Kit (QIAGEN, https:// www.qiagen.com) according to manufacturer instructions. We detected Zika virus RNA by qPCR (AgPath-ID, Applied Biosystems, https://www.thermofisher.com) on an ABI 7500 RT-PCR system (Applied Biosystems) using published primers that detect all known Zika virus genotypes (Zika1087/1108FAM/1163c) and those that are specific to the Asian genotype (Zika4481/4507cFAM/4552c) $(5,6)$. We added $8 \mu \mathrm{L}$ RNA to $12 \mu \mathrm{L} 2 \mathrm{X}$ RT-PCR buffer, 1 $\mu \mathrm{L}(10 \mathrm{pmol})$ each forward and reverse primers, $1 \mu \mathrm{L}(10$ pmol) probe, $1 \mu \mathrm{L}$ 25X RT-PCR enzyme mix, and $1.7 \mu \mathrm{L}$ detection enhancer to a final volume of $25 \mu \mathrm{L}$. We amplified Zika virus RNA at $50^{\circ} \mathrm{C}$ for $30 \mathrm{~min}$ and $95^{\circ} \mathrm{C}$ for 15 min, followed by 44 cycles of $95^{\circ} \mathrm{C}$ for $15 \mathrm{~s}$ and $60^{\circ} \mathrm{C}$ for 1 min. We used QIAGEN AVE buffer as negative RNA purification control and DEPC water as no-template control. The positive control was cell culture supernatant of the FP/2013 strain. We defined a positive sample as a cycle threshold $\left(\mathrm{C}_{\mathrm{t}}\right)<38$ in either reaction.

The study was approved by the institutional review boards of Universidad Nacional Autónoma de NicaraguaLeón (acta no. 86, 2016) and University of North Carolina at Chapel Hill (protocol no. 16-0541). All subjects provided written informed consent at enrollment.

Five women with acute Zika virus infection provided $\geq 1$ sample of vaginal secretions. The median age of these

${ }^{1}$ These authors contributed equally to this article. 
participants was 25 years (range 18-54 years). Four women were pregnant; gestational age at enrollment was 1-8 months. Infants of all 4 women were healthy at birth with no obvious congenital anomalies. The 54-year-old subject had hypertension; no other participants reported chronic medical conditions. Symptoms started a median of 4 days before enrollment (range 1-6 days).

No woman provided samples at all time points because of menstruation or lack of follow-up. Of 18 vaginal fluid specimens examined, 10 (56\%) were Zika virus positive by qRT-PCR with $\geq 1$ of the primer sets, and 3 were positive by both. Neither sample collected at 7 dpo was qRT-PCR positive, but $2 / 3(67 \%)$ were Zika virus positive at $14 \mathrm{dpo}$, $3 / 4(75 \%)$ at $21 \mathrm{dpo}, 1 / 3(33 \%)$ at $28 \mathrm{dpo}, 2 / 2(100 \%)$ at 60 dpo, $1 / 2(50 \%)$ at $90 \mathrm{dpo}$, and $1 / 2(50 \%)$ at $180 \mathrm{dpo}$. Three women had only 1 vaginal fluid sample positive for Zika virus by qRT-PCR; 1 had 2 of 3 positive; and 1 woman, who shed through $180 \mathrm{dpo}$, had Zika virus in 5 of 6 samples tested (Table).

\section{Conclusions}

Detection of Zika virus RNA in vaginal secretions 60 180 days after the onset of symptoms is a novel observation; the presence of Zika virus in vaginal secretions for $\leq 6$ months has crucial implications for couples planning pregnancy and for sexual transmission. In contrast to our results, in a population-based study of patients with symptomatic acute Zika virus infection followed for 6 months, only 1 of 50 women had Zika virus detectable in vaginal secretions, in a single specimen collected 3 dpo (4). The longest previously reported persistence of Zika virus RNA in vaginal secretions was 37 dpo (7); no other studies have detected Zika virus RNA in the reproductive tract for $>14$ dpo (8). Shedding was intermittent in several patients in our study, so 1 negative specimen does not necessarily signify viral clearance.

Most of our subjects were pregnant at enrollment; pregnant women are known to shed Zika virus in blood for up to 3 times longer than nonpregnant women, possibly because of fetal infection (9). Another study reported detection of Zika virus RNA in cervical cytology samples of 32 of 59 pregnant women compared with 18 of 109 nonpregnant women (10). Fetal tissue may act as a reservoir for long-term infection, or pregnancy-related immunosuppression might delay viral clearance. One patient in our study (A018) shed Zika virus RNA in the reproductive tract after delivery, suggesting that there may be reservoirs of viral replication in the female reproductive tract.

Our findings have implications for future pregnancies. Persistent Zika virus shedding in the reproductive tract could be a source of fetal infection. Vaginal shedding of Zika virus could result in ascending infection, as occurs with vaginal cervical herpesvirus 2 infections (11), or transmission during delivery, as seen with other viral infections such as human immunodeficiency virus and hepatitis B. Alternatively, transplacental infection may occur during viremia occurring after sexual transmission. Although the role of vaginal replication of Zika virus in fetal infection is not well characterized, mouse models suggest that fetal infection from vaginal sources of Zika virus replication can occur $(12,13)$.

Our findings also suggest that sexual transmission of Zika virus from women to their sexual partners may be possible for up to 6 months after infection. Infectivity studies are warranted to investigate whether Zika virus shed in vagina secretions is capable of replication and infection.

\begin{tabular}{|c|c|c|c|c|c|}
\hline Characteristic & A013 & A018 & $\mathrm{A} 020$ & $\mathrm{~A} 024$ & A039 \\
\hline Age, y & 54 & 18 & 25 & 19 & 25 \\
\hline Duration of symptoms at enrollment, $d$ & 1 & 3 & 4 & 6 & 5 \\
\hline Pregnant at enrollment & No & Yes & Yes & Yes & Yes \\
\hline Estimated gestational age at enrollment, mo & NA & 7 & 7 & 5 & 1 \\
\hline Timing of delivery, days after symptom onset & NA & 39 & 61 & 149 & 305 \\
\hline Hematocrit, \%, reference range $36-45$ & 36 & 32 & 35 & 37 & 40 \\
\hline Leukocytes, cells $/ \mathrm{mm}^{3}$, reference range $5,000-10,000$ & 4,230 & 5,410 & 3,510 & 17,430 & 8,050 \\
\hline Sexual contact in the last 3 mo $†$ & No & Yes & Yes & Yes & Yes \\
\hline Previous infection with dengue virus $†$ & Yes & No & No & No & No \\
\hline Previous infection with chikungunya virus $†$ & Yes & Yes & No & No & Yes \\
\hline Fluid Zika-positive by qRT-PCR at baseline & Saliva & Blood, urine & Blood & Urine & Blood, saliva \\
\hline \multicolumn{6}{|c|}{ Vaginal fluid PCR results, $C_{t} 1 / C_{t} 2, \ddagger$ at approximate days after symptom onset } \\
\hline 7 & NS & NS & NS & $0 / 0$ & $0 / 0$ \\
\hline 14 & NS & $31 / 0$ & $32 / 33$ & NS & $0 / 0$ \\
\hline 21 & NS & $35 / 0$ & $34 / 36$ & $0 / 0$ & $37 / 0$ \\
\hline 28 & $33 / 0$ & $0 / 0$ & NS & $0 / 0$ & NS \\
\hline 60 & NS & $34 / 36$ & NS & $36 / 0$ & NS \\
\hline 90 & NS & $35 / 0$ & NS & $0 / 0$ & NS \\
\hline 180 & NS & $37 / 0$ & $0 / 0$ & NS & NS \\
\hline
\end{tabular}

${ }^{*} \mathrm{C}_{t}$, cycle threshold; NA, not applicable; NS, no sample; qRT-PCR, quantitative reverse transcription PCR. 
Sexually acquired Zika virus, mainly by male-to-female transmission, has been reported in $\geq 18$ articles; however, there is evidence of infectious Zika virus particles in vaginal fluids (14). We lacked sufficient sample volumes to perform viral culture to distinguish between vaginal shedding of viral RNA and replication-competent virions, a limitation of our study. Only 1 report has documented the presence of culture-confirmed live Zika virus in vaginal secretions from an HIV-infected woman 3 dpo (14), and there is 1 reported case of likely female-to-male sexual transmission (15). Larger studies are needed to clarify the potential of the female reproductive tract to transmit Zika virus.

\section{Acknowledgments}

We thank Xiomara Obando for her clinical support and Aravinda de Silva for his laboratory support for serological testing.

This work was funded by US National Institute of Allergy and Infectious Diseases grant no. R21 AI129532 and an Emerging Challenges in Biomedical Research award from the University of North Carolina at Chapel Hill.

\section{About the Author}

Dr. Reyes is a medical microbiologist and junior faculty member at the Universidad Nacional Autónoma de Nicaragua-León, Nicaragua. Her main area of expertise is the molecular epidemiology of viruses of public health importance in Nicaragua, in particular gastrointestinal viruses and arboviruses. Dr. Bowman is an assistant professor in the Division of Infectious Diseases at the University of North Carolina School of Medicine. Her research focuses on vectorborne diseases in the Americas.

\section{References}

1. Paploski IAD, Prates APPB, Cardoso CW, Kikuti M, Silva MMO, Waller LA, et al. Time lags between exanthematous illness attributed to Zika virus, Guillain-Barré syndrome, and microcephaly, Salvador, Brazil. Emerg Infect Dis. 2016;22:143844. http://dx.doi.org/10.3201/eid2208.160496

2. Hills SL, Russell K, Hennessey M, Williams C, Oster AM, Fischer M, et al. Transmission of Zika virus through sexual contact with travelers to areas of ongoing transmission - continental United States, 2016. MMWR Morb Mortal Wkly Rep. 2016;65:215-6. http://dx.doi.org/10.15585/mmwr.mm6508e2

3. Brasil P, Pereira JP, Moreira ME, Ribeiro Nogueira RM, Damasceno L, Wakimoto M, et al. Zika virus infection in pregnant women in Rio de Janeiro. N Engl J Med. 2016;375:2321-34.

4. Paz-Bailey G, Rosenberg ES, Doyle K, Munoz-Jordan J, Santiago GA, Klein L, et al. Persistence of Zika virus in body fluids - final report. N Engl J Med. 2017;379:1234-43. http://dx.doi.org/10.1056/NEJMoa1613108

5. Lanciotti RS, Kosoy OL, Laven JJ, Velez JO, Lambert AJ, Johnson AJ, et al. Genetic and serologic properties of Zika virus associated with an epidemic, Yap State, Micronesia, 2007. Emerg Infect Dis. 2008;14:1232-9. http://dx.doi.org/10.3201/ eid1408.080287

6. Bingham AM, Cone M, Mock V, Heberlein-Larson L, Stanek D, Blackmore C, et al. Comparison of test results for Zika virus RNA in urine, serum, and saliva specimens from persons with travelassociated Zika virus disease-Florida, 2016. MMWR Morb Mortal Wkly Rep. 2016;65:475-8. http://dx.doi.org/10.15585/ mmwr.mm6518e2

7. Sánchez-Montalvá A, Pou D, Sulleiro E, Salvador F, Bocanegra C, Treviño B, et al. Zika virus dynamics in body fluids and risk of sexual transmission in a non-endemic area. Trop Med Int Health. 2018;23:92-100. http://dx.doi.org/10.1111/tmi.13019

8. Murray KO, Gorchakov R, Carlson AR, Berry R, Lai L, Natrajan M, et al. Prolonged detection of Zika virus in vaginal secretions and whole blood. Emerg Infect Dis. 2017;23:99-101. http://dx.doi.org/10.3201/eid2301.161394

9. Lozier MJ, Rosenberg ES, Doyle K, Adams L, Klein L, Muñoz-Jordan J, et al. Prolonged detection of Zika virus nucleic acid among symptomatic pregnant women: a cohort study. Clin Infect Dis. 2018;67:624-7. http://dx/doi.org/10.1093/cid/ciy209

10. Zambrano H, Waggoner J, León K, Pinsky B, Vera K, Schettino M, et al. High incidence of Zika virus infection detected in plasma and cervical cytology specimens from pregnant women in Guayaquil, Ecuador. Am J Reprod Immunol. 2017;77:12630. http://dx.doi.org/ 10.1111/aji.12630

11. McGee D, Smith A, Poncil S, Patterson A, Bernstein AI, Racicot K. Cervical HSV-2 infection causes cervical remodeling and increases risk for ascending infection and preterm birth. PLoS One. 2017;12:e0188645. http://dx.doi.org/10.1371/ journal.pone. 0188645

12. Yockey LJ, Varela L, Rakib T, Khoury-Hanold W, Fink SL, Stutz B, et al. Vaginal exposure to Zika virus during pregnancy leads to fetal brain infection. Cell. 2016;166:1247-1256.e4. http://dx.doi.org/10.1016/j.cell.2016.08.004

13. Winkler CW, Woods TA, Rosenke R, Scott DP, Best SM, Peterson KE. Sexual and vertical transmission of Zika virus in anti-interferon receptor-treated Rag1-deficient mice. Sci Rep. 2017;7:7176. http://dx.doi.org/10.1038/s41598-017-07099-7

14. Penot $\mathrm{P}$, Brichler S, Guilleminot J, Lascoux-Combe C, Taulera $\mathrm{O}$, Gordien $\mathrm{E}$, et al. Infectious Zika virus in vaginal secretions from an HIV-infected woman, France, August 2016. Euro Surveill. 2017;22:30444. http://dx.doi.org/10.2807/ 1560-7917.ES.2017.22.3.30444

15. Davidson A, Slavinski S, Komoto K, Rakeman J, Weiss D. Suspected female-to-male sexual transmission of Zika virusNew York City, 2016. MMWR Morb Mortal Wkly Rep. 2016; 65:716-7. http://dx.doi.org/10.15585/mmwr.mm6528e2

Address for correspondence: Natalie M. Bowman, University of North Carolina at Chapel Hill School of Medicine, CB\#7030, Bioinformatics Building, 2nd Fl, 130 Mason Farm Rd, Chapel Hill, NC 27999-7030, USA; email: nbowman@med.unc.edu 